\title{
Understanding Teacher's Motivation to Choose Teaching English as a Career Choice
}

\author{
Titapond Poomdaeng * Denchai Prabjandee Punwalai Kewara \\ Faculty of Education, Burapha University, 169 LongHad Bangsaen RD, Chonburi 20131, Thailand \\ * E-mail of the corresponding author: poo.titaporn24@gmail.com
}

\begin{abstract}
The purposes of this study were to investigate 176 pre-service teacher graduates' motivation to choose teaching English as a career choice, to compare the motivation between males and females, and between those who decide to enter the teaching profession and those who decide not to enter the teaching profession. A questionnaire was used to collect the data, consisting of three domains: intrinsic, extrinsic, and altruistic motivation. The findings revealed that the motivation to choose teaching English as a career choice was mainly altruistic; they see teaching as a socially worthwhile and important job, a desire to improve society, help others and make a difference. The findings also illustrated that pre-service teacher graduates' motivation to choose teaching English as a career choice was significantly different between males and females. Finally, there were no significant differences in motivation to choose teaching English as a career choice between those who decide to enter the teaching profession and those who decide not to enter the teaching profession.
\end{abstract}

Keywords: pre-service teachers, career motivation, teacher motivation

DOI: $10.7176 / \mathrm{JEP} / 11-12-04$

Publication date: April $30^{\text {th }} 2020$

\section{Introduction}

Nowadays, English is the first language of not only countries actively touched by British imperialism, but many business and cultural spheres dominated by those countries too. It is the language of Hollywood and the language of international banking and business. As such, it is a beneficial and even necessary language to know. Further, English is essential in the field of education. In many countries, children are taught and encouraged to learn English from a very young age. Given the importance of English, pre-service English teachers are very important as well because they are prospective teachers who may enter the teaching profession. Thailand is facing problems about the teacher shortage, especially English teachers (Prabjandee, 2014). The teacher shortage crisis already exists in some geographic areas and subjects, and further shortages are forecasted (OECD, 2005; Preston, 2002). Difficulty in attracting new recruits to initial teacher education courses, the resignation of qualified teachers and retirement of an ageing teacher labor force are all reported as the main causes of existing and potential shortages (Bradley, Sampson, Ma, \& Cunningham, 2006; Johnson \& Birkeland, 2002; O’Connor, 1999; Preston, 2002; Ramsay, 2000; Tabberer, 2003).

As a result, the teacher shortage influences the motivation of pre-service teachers and they decide to change to other careers. When teacher recruitment is concerned, it is claimed that the profession fails to attract bright young people (Murnane, Singer, Willett, Kemple, \& Olsen, 1991; Kyriacou \& Coulthard, 2000). Many other motivations inside and outside the family have also been linked with career choices in the teaching profession and other professions. It has some structural, social and psychological reasons (Ingersoll, 2001; Lai, Mok, Ko, \& Li, 2000; Menter, Hutchings, \& Ross, 2002).

\section{Statement of the problem}

Research on motivation to choose teaching English as a career choice has been carried out in many countries, such as Turkey (Boz \& Boz, 2008; Ubuz \& Sar1, 2008), Singapore (Hayes, 1990), and Australia (Watt and Richardson (2007). For instance, Boz and Boz (2008) found that the participants reported having more intrinsic reasons to become teachers than extrinsic and altruistic reasons. Similar findings were reported in other studies found in the Turkish context (Aksu et al., 2010; Gürbüz \& Sülün, 2004; Saban, 2002; Topkaya \& Uztosun, 2012). In contrast, Ubuz and Sar1 (2008) reported more extrinsic reasons, one of which was job opportunities. Moreover, in Australia, such altruistic reasons are ranked high by Watt and Richardson (2007). In the same, Singapore reported that $92 \%$ of college students majoring in education reported altruistic reasons (Hayes, 1990). Based on this difference, it can be concluded that context is important. However, extensive review of the literature found that limited research was explored motivation to enter the teaching profession in Thailand, especially English teachers.

In addition, the teaching profession has been regarded as a female profession because the world has faced the lack of male pre-service teacher graduates. According to the Consortium for Policy Research in Education in 2012, only 24 percent of all teachers were male, with just one in 10 men teaching elementary school students (Deese, 2007). It is therefore important to point out that previous research argued gender might play an important role in the motivation to choose teaching as a career choice. It was related to the differences between pre-service teacher 
graduates' motivations to choose teaching English as a career choice between males and females. For example, Balyer and Özcan (2014) reported that females from Turkey choose intrinsic, while males reported having extrinsic reasons.

Moreover, there have not been any studies to compare the motivation to choose teaching English as a career choice between those who decide to enter the teaching profession and those who decide not to enter the teaching profession. Most of the studies focused on motivation to choose teaching English as a career choice and differences between pre-service teacher graduates' motivations to choose teaching English as a career choice between males and females. Therefore, in order to understand a phenomenon more, it is important to investigate pre-service teacher graduates' motivation to choose teaching English as a career choice. Moreover, it is necessary to understand more about the differences between pre-service teacher graduates' motivations to choose teaching English as a career choice between males and females and differences between those who decide to enter the teaching profession and those who decide not to enter the teaching profession.

\section{Literature review}

This part reviews three sections, which are motivation to choose teaching as a career, types of motivation to choose as a career and different reasons to choose teaching as a career.

\subsection{Motivation to choose teaching as a career}

Motivation refers to what moves a person to make certain choices, effort and engage in action and to expend (Dörnyei \& Ushioda, 2011). For student teachers, their motivations can determine and affect how long they remain in their initial teacher education courses and subsequently the teaching profession and the extent to which they engage with (concentrate on) their courses and the profession (Sinclair, 2008). Student teachers normally have multiple motivations that describe why they choose to enter and stay in the teaching profession (Gao \& Trent, 2009; Kyriacou \& Kobori, 1998), which can be altruistic (e.g., a desire to help children succeed), intrinsic (e.g., in teaching itself or an interest in the subject), and extrinsic (e.g., long holidays and salaries). As Dörnyei and Ushioda (2011) pointed out, teacher motivation involves a prominent intrinsic component, that is more likely to sustain over time and can better support teachers in the complex process of learning to teach than other extrinsic reasons (Sinclair, Dowson, \& McInerney, 2006; Young, 1995). In general, teacher motivations are not set in stone but subject to change, which can be ascribed to their individual background and their pre-service training, personal beliefs, as well as the socio-cultural contexts in which their future work is embedded (Gao \& Trent, 2009; Watt \& Richardson, 2008).

\subsection{Types of motivation to choose teaching as a career}

Traditionally, reasons for choosing to teach have been treated under three broad categories which are intrinsic, extrinsic, and altruistic, as described below.

Intrinsic motivation covers aspects of the job activity itself, such as, an interest in using their subject matter knowledge, the activity of teaching children and expertise, as well as personal interest, intellectual fulfillment, the enjoyment of teaching and the school environment (Brookhart \& Freeman, 1992; Moran et al., 2001; Chong \& Low, 2009).

Extrinsic motivation covers aspects of the job which are not inherent in the work itself, such as level of pay, long holidays, and status. Moreover, some research shows that pre-service teachers are motivated to join the profession with mostly extrinsic reasons (Chan, 1998). In the same way, extrinsic reasons also refer to economic and conditions of service and social status. It is considered that students are interested in teaching as a career or job, and generally regard teaching as a preferred and respected occupation (Lai, Ko, \& Li, 2000). Pre-service teachers who are interested in teaching consider a teaching career for its enormous contribution to society, good working conditions and good salaries. The security of employment presented by teaching and the attractive working hours and longer holidays (Butcher \& Lewis, 2002; Knobloch, 2005; Stiegelbauer, 1992; Hayes, 2000). (Brookhart \& Freeman, 1992; Moran et al., 2001; Chong \& Low, 2009).

Altruistic motivation deals with seeing teaching as a socially worthwhile and important job, a desire to improve society, make a social contribution, and being part of children's and young peoples' growth and development (Brookhart \& Freeman, 1992; Moran et al., 2001; Chong \& Low, 2009).

\subsection{Different reasons to choose teaching as a career}

Different studies suggest and advise that people have different reasons for becoming teachers. Some studies indicate that students want to become teachers because of extrinsic reasons (Papanastasiou and Papanastasiou 1997; Yong 1995), for instance, stable employment immediately after completing their education or long vacations. However, both Norwegian and international studies point that altruistic and intrinsic reasons dominate the choice of teaching as a profession. International findings show that a desire to work with children in order to make a difference in their live, personal fulfilment, s, meaningful engagement with the academic subject of their choice 
(Manuel and Hughes 2006), a sense of vocation and the fulfilment of a dream, making a contribution to society (Manuel and Brindley 2005), are common reasons for choosing the teaching profession. In Norway, research is limited, but the few studies that have been carried out indicate that an enjoyment of working with children seems to be an important reason for becoming a teacher (Holm 1975; Holm 1989). Student teachers regard the teaching profession as a worthwhile and challenging profession too (Bergem 1994).

The aforementioned studies have mainly dealt with students who were beginning teacher education of elementary school. Regarding teacher education of secondary school, we can find similar altruistic and intrinsic reasons (see for example Reid and Caudwell 1997; Thornton et al. 2002). We can, however, notice a change in the direction towards more academically oriented reasons too. Jarvis and Woodrow (2005) have found that student motivation is career-related. A challenging, rewarding career and stable and a wish to continue working with the specific subject matter are the most preferred reasons for taking a Postgraduate Certificate in Education (PGCE) course. The comparative study between Norwegian and English PGCE students by Kyriacou et al. (1999) indicates that an interest in the subject matter and a satisfaction in working with children are the main reasons for becoming teachers. Roness and Smith (2009) have noted that the wish to make pupils interested in the subject, the enjoyment of working with the academic subject, and the meaningfulness of working with children and youth are the main motivational sources for engaging in teacher education among Norwegian student teachers.

Research informs us that the motivating factors mentioned above are typical motivators behind the wish to become a teacher. There are, however, other factors worth mentioning. Watt and Richardson (2008) characterized a group of teachers as 'highly engaged switchers', meaning that these individuals are engaged teachers who are in the profession more for the experience than for a career in teaching. Smethem (2007) has presented the concept of 'portfolio teachers' who see teaching only as a stepping stone in their career trajectory. Anthony and Ord (2007) reported that among 'change-of-career' secondary-school teachers, there are pragmatic reasons that seem to be salient when they enter the profession.

\section{The Present Study}

4.1 Research Questions

1. What are pre-service teacher graduates' motivation to choose teaching English as a career choice?

2. Are there any differences in motivation to choose teaching English as a career choice between males and females? 3. Are there any differences in motivation to choose teaching English as a career choice between those who decide to enter the teaching profession and those who decide not to enter the teaching profession?

\subsection{Research Design}

This study used a quantitative research approach with a survey research design to collect the data. Quantitative research deals with numeric, quantified, and measurable data. Specifically, in this study, the motivation to choose teaching English as a career choice was quantified into number. According to Creswell (2012), the survey approach is a step in which a researcher conducts a survey to a group of people in order to identify trends in attitudes, opinions, or behaviors. The trend in this study was motivation to choose teaching English as a career choice. This design is suitable to apply to find answers to the objectives of the study, which were to investigate pre-service teacher graduates' motivation to choose teaching English as a career choice, to compare males and females, and to compare those who decide to enter the teaching profession and those who decide not to enter the teaching profession.

\subsection{Population and Participants}

The target population was pre-service teacher gradates with an English teaching major from a university located in the eastern part of Thailand. The participants were English major graduates from the Faculty of Education. The estimated number of participants needed to conduct statistical tests with sufficient power is 176, calculated by using the G*Power Software (Erdfelder, Faul, \& Buchner, 1996) with the small effect size of .25, statistical power of .7, and alpha level of .05. The participants were selected by using the volunteer sampling and snowball sampling techniques.

Table 1. Frequency and Percentage of the Respondents' Gender.

\begin{tabular}{lll}
\hline Gender & Participants & Percentage \\
\hline Male & 35 & 19.9 \\
Female & 141 & 80.1 \\
\hline Total & $\mathbf{1 7 6}$ & $\mathbf{1 0 0 . 0}$ \\
\hline
\end{tabular}

As shown in Table 1, there are 35 male learners (19.9\%) and 141 female learners $(80.1 \%)$. 


\begin{tabular}{lll}
\hline & Table 2. Frequency and Percentage of the Respondents' Career. \\
\hline Career & Frequency & Percentage \\
\hline Teacher & 150 & 85.2 \\
Employee & 18 & 10.3 \\
Flight attendant & 1 & 0.6 \\
Student & 1 & 0.6 \\
Self-employed & 5 & 2.8 \\
Unemployed & 1 & 0.6 \\
\hline Total & $\mathbf{1 7 6}$ & $\mathbf{1 0 0 . 0}$ \\
\hline
\end{tabular}

Table 2 shows that out of 176 respondents, $85.2 \%$ of pre-service teacher graduates decided to enter the teaching profession, while $14.8 \%$ chose other careers, such as employee $(10.3 \%)$, flight attendant $(0.6 \%)$, student $(0.6 \%)$, self-employed (2.8\%), and unemployed $(0.6 \%)$.

\subsection{Research Instruments}

The questionnaire on motivation to choose teaching English as a career choice was developed based on the tripartite framework by Kyriacou et al. (1999) First, intrinsic motivation refers to the drive from within an individual, such as enjoyment of teaching children, an interest in using their subject matter knowledge, expertise and involved a joy and love of doing an activity as well as a personal internal judgement of success. Second, extrinsic motivation refers to the drive from outside an individual, such as having long holidays, level of pay, status and involved an external force or reward as well as convenience and ease. Finally, altruistic motivation refers to seeing teaching as a socially worthwhile and important job, a desire to improve society, help others, and make a difference. Based on the framework, the statements were developed.

In the questionnaire, pre-service teacher graduates were asked to complete the questionnaire which was made up of a few questions related to their background information such as, gender and career. The 32 items were organized into three parts: intrinsic (11 items), extrinsic (15 items), and altruistic motivation (6 items). In this part, the respondents were requested to indicate the agreement by using a five-point Likert scale.

\subsection{Data Collection and Analysis}

In this research, Google form was used to collect the data. The questionnaire was posted in a closed Facebook group of pre-service English teachers. This group contained 200 people. They had graduated with a major in English teaching from 2012-2016. After four days of posts, only 15 responses were received, so I decided to send a personal message on Facebook to request their cooperation. Based on this method, 176 responses were received in one month.

RQ 1: What are pre-service teacher graduates' motivation to choose teaching English as a career choice?

To answer this question, descriptive statistics (means and standard deviations) were used. The means and standard deviations were used to measure the categories of motivation for choosing English as a career. The following criteria was used.

RQ 2: Are there any differences in motivation to choose teaching English as a career choice between males and females?

This question aimed at making comparisons of pre-service teacher graduates' English as a career conduct by males and females. Therefore, an Independent t-test was used to make a means comparison.

RQ 3: Are there any differences in motivation to choose teaching English as a career choice between those who decide to enter the teaching profession and those who decide not to enter the teaching profession?

This question aimed at making comparisons of motivation to choose teaching English as a career choice and the decision to enter the teaching profession. Therefore, an Independent t-test was used to make a means comparison.

\section{Findings}

This chapter presents the findings collected from the survey data on pre-service teacher graduates' motivation to choose teaching English as a career choice. It also attempts to find the differences between pre-service teacher graduates' motivation to choose teaching English as a career choice between males and females and examine the difference motivation to choose teaching English as a career choice between those who decide to enter the teaching profession and those who decide not to enter the teaching profession. In this chapter, the findings are presented based on the order of the research questions.

\subsection{Findings of Research Question 1}

What are pre-service teacher graduates' motivation to choose teaching English as a career choice?

This section reports the answers to the first research question by using descriptive statistics. The means and standard deviations are reported to measure the categories of motivation for choose teaching English as a career. 
Table 3 presents the descriptive statistics of motivation to choose teaching English as a career choice.

Table 3. Descriptive statistics of motivation to choose teaching English as a career choice.

\begin{tabular}{|c|c|c|}
\hline \multirow[t]{2}{*}{ Categories } & \multicolumn{2}{|c|}{$N=176$} \\
\hline & $\overline{\boldsymbol{X}}$ & SD \\
\hline Altruistic & 4.03 & 0.58 \\
\hline Intrinsic & 3.74 & 0.40 \\
\hline Extrinsic & 3.59 & 0.51 \\
\hline Total & 3.79 & 0.41 \\
\hline
\end{tabular}

As shown in Table 3, the data reveals that the participants decided to choose teaching English as a career choice because of altruistic reasons the most $(M=4.03, S D=0.58)$, followed by intrinsic reason $(M=3.74, S D=$ $0.40)$, and extrinsic reasons $(M=3.59, S D=0.51)$. This indicates that the majority of the participants chose teaching English because they see teaching as a socially worthwhile and important job, a desire to improve society, help others and make a difference.

\subsection{Findings of Research Question 2}

Are there any differences in motivation to choose teaching English as a career choice between males and females?

This section presents the data to answer the third research question. To answer the question, an Independent t-test was performed as shown in Table 4.

Table 4. Comparison of motivations to choose teaching English as a career choice between males and females.

\begin{tabular}{llllll}
\hline & Career & M & SD & $\boldsymbol{t}$ & Sig \\
\hline extrinsic & Male & 3.90 & 0.43 & 4.12 & $.00^{*}$ \\
& Female & 3.52 & 0.50 & 4.54 & $.001^{*}$ \\
\hline intrinsic & Male & 3.89 & 0.24 & 2.47 & $.017^{*}$ \\
& Female & 3.71 & 0.42 & 3.43 & 2.41 \\
\hline altruistic & Male & 4.24 & 0.43 & 2.91 & \\
& Female & 3.98 & 0.60 & & \\
\hline
\end{tabular}

$* \mathrm{p}<.05$

Table 4 presents a comparison of motivation to choose teaching English as a career choice between males and females pre-service teacher graduates. It was revealed that there was a significant difference in all types of motivation. For extrinsic motivation, males reported having more intrinsic motivation $(\mathrm{M}=3.90, \mathrm{SD}=0.43)$ than females $(\mathrm{M}=3.52, \mathrm{SD}=0.50)$ conditions; $\mathrm{t}(174)=4.12, \mathrm{p}=0.00$.

For intrinsic, there was a significant difference in the intrinsic motivation for males $(\mathrm{M}=3.89, \mathrm{SD}=0.24)$ and females $(\mathrm{M}=3.71, \mathrm{SD}=0.42)$ conditions; $\mathrm{t}(174)=2.47, \mathrm{p}=0.001$. Moreover, there was a significant difference in the altruistic motivation for males $(\mathrm{M}=4.24, \mathrm{SD}=0.43)$ and females $(\mathrm{M}=3.98, \mathrm{SD}=0.60)$ conditions; $\mathrm{t}(174)=2.41, \mathrm{p}=0.017$.

\subsection{Findings of Research Question 3}

Are there any differences in motivation to choose teaching English as a career choice between those who decide to enter the teaching profession and those who decide not to enter the teaching profession?

This section presents the data to answer the third research question. To answer the question, an Independent t-test was performed as shown in Table 5.

Table 5. Differences between those who decide to enter the teaching profession and those who decide not to enter the teaching profession.

\begin{tabular}{llllll}
\hline \multirow{2}{*}{ Altruistic } & Career & M & SD & $\boldsymbol{t}$ & Sig \\
& Teacher & 4.04 & 0.60 & 0.37 & .08 \\
& Others & 3.99 & 0.43 & 0.46 & .10 \\
\hline \multirow{2}{*}{ Extrinsic } & Teacher & 3.74 & 0.42 & 0.01 & \\
& Others & 3.74 & 0.29 & 0.01 & .30 \\
& Teacher & 3.61 & 0.51 & 0.86 & 0.90 \\
\hline
\end{tabular}

$* \mathrm{p}<.05$

Table 5 presents a comparison of motivation to choose teaching English as a career choice between those who decide to enter the teaching profession and those who decide not to enter the teaching profession. It was revealed that there was no significant difference in all types of motivation. For altruistic motivation, pre-service teachers decide to enter the teaching profession reported having more altruistic motivation $(\mathrm{M}=4.04, \mathrm{SD}=0.60)$ than pre-service teachers decide not to enter the teaching profession $(\mathrm{M}=3.99, \mathrm{SD}=0.43)$ conditions; $\mathrm{t}(174)=$ $0.37, \mathrm{p}=0.08$. For, intrinsic there was no significant difference in the intrinsic motivation for pre-service teachers 
decide to enter the teaching profession $(\mathrm{M}=3.74, \mathrm{SD}=0.42)$ and pre-service teachers decide not to enter the teaching profession $(\mathrm{M}=3.74, \mathrm{SD}=0.29)$ conditions; $\mathrm{t}(174)=0.42, \mathrm{p}=0.10$. Moreover, there was no significant difference in the extrinsic motivation for pre-service teachers decide to enter the teaching profession $(\mathrm{M}=3.61$, $\mathrm{SD}=0.51)$ and pre-service teachers decide not to enter the teaching profession $(\mathrm{M}=3.51, \mathrm{SD}=0.48)$ conditions; $\mathrm{t}(174)=0.86, \mathrm{p}=0.30$.

Moreover, the details of each motivation as reported by pre-service teachers who decide to enter the teaching profession and pre-service teachers who decide not to enter the teaching profession. It is valuable to point out some interesting statements. For intrinsic, pre-service teachers decide to enter the teaching profession reported higher average scores $(\mathrm{M}=17.33)$ in the statement of "They want a job that involves working with children and adolescents" than pre-service teachers decide not to enter the teaching profession. $(\mathrm{M}=0)$. For extrinsic, preservice teachers decide to enter the teaching profession reported higher average scores $(M=27.33)$ in the statement of "Teaching provides a reliable income." than pre-service teachers decide not to enter the teaching profession (M $=3.84$ ). For altruistic, pre-service teachers decide to enter the teaching profession reported higher average scores $(\mathrm{M}=28.66)$ in the statement of "Teaching allows me to inspire the next generation." than pre-service teachers decide not to enter the teaching profession $(\mathrm{M}=11.53)$.

\section{Discussion}

This section provides a discussion of the research findings in the current study. The discussion focuses on the preservice teacher graduates' motivations to choose teaching English as a career choice and the differences between pre-service teacher graduates' motivations to choose teaching English as a career choice between males and females, and the differences of those who decide to enter the teaching profession and those who decide not to enter the teaching profession. The following discussion is based on the analysis in the previous chapter.

\subsection{Motivations to Choose Teaching English as a Career}

The findings from the study indicate that the pre-service teachers graduates' motivations to choose teaching English as a career choice, as measured by the means. The results indicate that the pre-service teacher graduates' motivations to choose teaching English as a career choice is because of altruistic reason the most, followed by intrinsic reason, and extrinsic reasons. This indicates that the majority of the participants chose teaching English because they see teaching as a socially worthwhile and important job, a desire to improve society, help others and make a difference. Moreover, the desire to contribute to individual and social development. In western countries, the most reasons for choosing teaching as a career were altruistic and intrinsic motives (Ewing and Manuel, 2005; Goh \& Atputhasamy, 2001; Hayes, 1990; Kyriacou \& Coulthard, 2000; Kyriacou et al., 2003; Ling Low et al., 2011; Manuel, 2003; Priyadharshini and Robinson-Pant 2003; Reid and Caudwell 1997; Spear et al., 2000; Yong 1995). In agreement with Bastick (2000), preservice teachers in developed societies also choose teaching for altruistic and intrinsic motives, but in developing and underdeveloped societies, most pre-service teachers choose extrinsic motives. Moreover, Sinclair (2008) found that young people are motivated to teach not by only one motive but by many reasons such as being a service to people, working conditions, social status, appropriateness to personality and prestige, appointment, etc. The current findings also support the findings of many related studies in western communities (Bastick, 2000; Reid \& Caudwell, 1997; Hayes, 1990; Kyriacou et al., 2003; Papanastasiou, 1998; Watt et al., 2012; Watt and Richardson, 2007). These studies show that altruistic motivation has a preponderant role in choosing teaching as a career. For example, Kyriacou et al., (2003) found that English and Norwegian pre-service teachers chose teaching as a career, since it best suited their personalities. In another study, Hayes (1990) found that pre-service teachers from America chose teaching with altruistic motives too.

\subsection{Gender}

All of them were significance differences. The most was extrinsic, there was a significant difference in the altruistic motivation for males and females. For intrinsic, there was a significant difference for males and females. And, there was a significant difference in the altruistic motivation for males and females. There is also a difference between "salary" and "working with children" factors in terms of gender. In other words, while women prefer working with children, males prefer salary. However, male participants choose teaching English as a career choice with intrinsic, extrinsic and altruistic more than female participants. Males choose teaching English as a career choice with altruistic the most, followed by extrinsic and intrinsic. But for females, they choose teaching English as a career choice with altruistic most, followed by intrinsic and extrinsic. Other researchers have found that males choose the profession for its status, salary and career opportunities. In this regard, male students are more influenced by status, salary and career opportunities. According to them, the factors influencing the choice of primary teaching as a career option among six formers differed significantly between males and females. (Newby, Smith, Newby, \& Miller, 1995; Butcher \& Lewis, 2002; Johnston, McKeown, \& McEwen, 1999; Foster \& Newman, 2005; Saban, 2003; Smedley, 2007; Parr, Gosse, \& Allison, 2008; Ozbek, 2007; Sahin, Cokadar, \& Usak, 2008). In some studies, it was found that female teachers choose this career with intrinsic reasons different 
from males (Saban, 2003; Boz \& Boz, 2008; Haciomeroglu \& Sahin, 2009; Johnston, McKeown, \& McEwen, 1999).

\subsection{Decision}

There were no statistically significant differences in motivation to choose teaching English as a career choice between those who decide to enter the teaching profession and those who decide not to enter the teaching profession. For pre-service teacher graduates who decide to enter the teaching profession with altruistic most, followed by intrinsic and extrinsic. Similarly, pre-service teacher graduates who decide not to enter the teaching profession with altruistic most, followed by intrinsic and extrinsic.

\section{Implications}

The present study sheds lights on the ideas of commonly used motivation to choose teaching English as a career choice in English teaching as major at a university in the eastern part of Thailand. The findings can help and are useful in English education to understand more and to carry on conducting other research studies to enrich the information. This will enable deeper insights in order to help educators, administrators, curriculum designers, material developers, educational technologists, and relevant education workers to incorporate and integrate.

Moreover, this research found that pre-service teacher graduates choose altruistic motivation most. Their attitudes are seeing teaching as a socially worthwhile and important job, a desire to improve society, help others and make a difference. So, universities should choose pre-service teachers who are quality people and suitable as English teachers. They should choose pre-service teachers who have altruistic motivation as shown in this research. They must want to see teaching as a socially worthwhile and important job, a desire to improve society, help others and make a difference.

However, there should be a policy related to extrinsic motivation too because this research found that preservice teachers who decide not to enter the teaching profession choose extrinsic last. So, having policies such as, salary and long holidays would encourage them more to be a teacher.

\section{Recommendations for Future Studies}

This study suggests that future researchers should investigate the pre-service teacher graduates' motivations to choose teaching English as a career choice and explore other variables, including but not limited to the variables investigated in the current study. However, policy makers should consider extrinsic because most pre-service teacher graduates did not choose extrinsic, such as, salary and long holidays. Moreover, future studies should solve the problem related to the lack of male pre-service teachers.

\section{References}

Aksu, M., Demir, C. E., Dalog lu, A., Yıldırım, S., \& Kiraz, E. (2010). Who are the future teachers in Turkey? Characteristics of entering student teachers. Journal of Educational Development, 30, 91-101.

Anthony, G., and K. Ord. 2007. Change-of-career secondary teachers: Motivations, expectations and intentions. Asia-Pacific Journal of Teacher Education 36, no. 4: 359-76.

Balyer, A., \& Ozcan, K. (2014). Choosing teaching profession as a career: students' reasons, International Education Studies, 7( 5), 104-115

Bastick, T. (2000). Why teacher trainees choose the teaching profession: Comparing trainees in metropolitan and developing countries. International Review of Education, 6(3), 343-349.

Bergem, T. 1994. Tjener - aldri herre: om lærerutdanning og yrkesetiske holdninger: sluttrapport fra LYHprosjektet [Servant - never master: About teacher education and ethical attitudes in work]. Bergen: NLAforlaget.

Boz, Y., \& Boz, N. (2008). Kimya ve matematik öğretmen adaylarının öğretmen olma nedenleri. Kastamonu Ĕ̈itim Dergisi, 16(1), 137-144.

Bradley, K. D., Sampson, S. O., Ma, L., \& Cunningham, J. D. (2006). Where are the teaching opportunities? A longitudinal study of educator supply and demand. Retrieved from http://www.tcrecord.org/Home.asp.

Brookhart, S. M., \& Freeman, D. J. (1992). Characteristics of entering teacher candidates. Review of Educational Research, 62, 37-60.

Butcher, J., \& Lewis, E. (2002). Why not teaching? Senior students have their say. In the Australian Association for Research in Education Conference, Brisbane. Dec. 1-5.

Chan, K. W. (1998). The role of motives in the professional development of student teachers. Education Today, $48(1), 2-8$.

Chong, S. \& Low, E. L. (2009). Why I want to teach and how I feel about teaching- formation of teacher identity from pre-service to the beginning teacher phase. Educational Research Policy and Practice, 8, 59-72.

Creswell, J. (2012). Educational research: Planning, conducting, and evaluating quantitative and qualittive research (4th ed.). Boston: Pearson. 
Deese, H. (2017). Male teacher shortage affects boys who need role models. Retrieved January 5, 2019, from https://www.usatoday.com/story/news/2017/07/22/male-teacher-shortage-affects-boys-who-need-rolemodels/103585138/?fbclid=IwAR3KvzYZJpHk4ZyPycPY6fQ3aYzVIkhooQnLLQPm0xYyq2ccCPYvmV $\mathrm{M}-\mathrm{vFI}$

Dörnyei, Z., \& Ushioda, E. (2011). Teaching and researching motivation (2nd ed.). New York, NY: Longman.

Erdfelder, E., Faul, F., \& Buchner, A. (1996). GPOWER: A general power analysis program. Behavior Research Methods, Instruments, \& Computers, 28(1), 1-11.

Ewing, R., \& Manuel, J. (2005). Retaining quality early career teachers in the profession: New teacher narratives. Change: Transformations in Education, 7(1), 4-18.

Foster, T., \& Newman, E. (2005). Just a knock back? Identity bruising on their route to becoming a male primary school teacher. Teachers and Teaching: Theory and Practice, 11(4), 341-358.

Gao, X. S., \& Trent, J. (2009). Understanding mainland Chinese students' motivations for choosing teacher education programmes in Hong Kong. Journal of Education for Teaching: International Research and Pedagogy, 35(2), 145-159

Goh, K. C., \& Atputhasamy, L. (2001, December). Factors motivating the young adults to choose teaching as a career in Singapore. In the International Educational Research Conference, University of Notre Dame, Fremantle, Western Australia

Gürbüz, H., \& Sülün, A. (2004). Türkiye'de biyoloji öğretmenleri ve biyoloji öğretmen adaylarinin nitelikleri. Milli Eğitim Dergisi, 161, 192-204.

Haciomeroglu, G., \& Sahin, T. C. (2009). Ogretmen adaylarinin ogretmenlik mesleğini tercih sebepleri. I. Uluslar arasi Turkiye Egitim Arastırmalari Kongresi, Canakkale Onsekiz Mart Universitesi. Canakkale, 01-03 May1s [In Turkish].

Hayes, D. (2000). Mediating influences in the preparation of student primary teachers: Issues relating to school placements. In the Annual Conference of the British Educ Res Assoc, Cardiff, September 7-10.

Hayes, S. 1990, Students' reasons for entering the educational profession, Research Report, Oklahoma: Northwestern Oklahoma State University, 35 pp.

Holm, G. 1975. Lærer- Hvorfor? [Teacher - Why?]. Oslo: Universitetet i Oslo.

Holm, G. 1989. Lærer- Hvorfor II Oppfølgingsundersøkelse om motivasjon for læreryrket blant søkere til allmennlærerutdanning 1974 og 1982 [Teacher - Why? II. A follow-up study about motivation for becoming a teacher among applicants to initial teacher education 1974 and 1982]. Oslo: Nesna Lærerhøgskoles skriftserie.

Ingersoll, R. (2001). Teacher turnover, teacher shortages, and the organization of schools. Center for the Study of Teacher and Policy. University of Washington, Seattle.

Jarvis, J., \& Woodrow, D. (2005). Reasons for choosing a teacher training course. Research in Education, 73(1), 29-35.

Johnson, S. M., \& Birkeland, S. E. (2002). Pursuing a "sense of success": New teachers explain their career decisions. Project on the next generation of teachers. American Educational Research Journal, 40(3), 581617.

Johnston, J., McKeown, E., \& McEwen, A. (1999). Choosing primary teaching as a career: The perspectives of males and females in training. Journal of Education for Teaching, 25(1), 55-64.

Knobloch, L. K. (2005). Evaluating a contextual model of responses to relational uncertainty increasing events: The role of intimacy, appraisals, and emotions. Human Comunication Research, 3(1), 60-101.

Kyriacou, C., \& Coulthard, M. (2000). Undergraduates' views of teaching as a career choice. Journal of Education for Teaching, 26(2), 117-126.

Kyriacou, C., Hultgren, A., \& Stephens, P. (1999). Student teachers' motivation to become a secondary school teacher in England and Norway. Teacher Development, 3(3), 373-381.

Kyriacou, C., Kunc, R., Stephens, P., \& Hultgren, A. (2003). Student teachers' expectations of teaching as a career in England and Norway. Educational Review, 55(3), 255-263.

Kyriacou, C., \& Kobori, M. (1998). Motivation to learn and teach English in Slovenia. Educational Studies, 24(3), $345-351$.

Lai, K. C., Ko, K. W., \& Li, C. (2000). A study on secondary 6 students' knowledge of teacher education and their perception of teaching as a career in Hong Kong. Hong Kong: Office of Planning and Academic Implementation, Hong Kong Institute of Education.

Ling Low, E., Khoh Lim, S., Ch'ng, A., \& Goh Chuan, K. (2011). Pre-service teachers' reasons for choosing teaching as a career in Singapore. Asia Pacific Journal of Education, 31(2), 195-210.

Manuel, J. (2003). 'Such are the ambitions of youth': Exploring issues of retention and attrition of early career teachers in New South Wales. Asia-Pacific Journal of Teacher Education, 31(2), 139-151.

Manuel, J., \& Brindley, S. (2005). The call to teach: Identifying pre-service teachers' motivations, expectations and key experiences during initial teacher education in Australia and the United Kingdom. English in 
Australia, 144, 38-49.

Manuel, J., \& Hughes, J. (2006). 'It has always been my dream': Exploring pre-service teachers' motivations for choosing to teach. Teacher Development, 10, 5-24.

Menter, I., Hutchings, M., \& Ross, A. (2002). The crisis in teacher supply: Research and strategies for retention. Wiltshire: Cormwell Press.

Moran, A., Kilpatrick, R., Abbot, L., Dallat, J., \& McClune, B. (2001). Training to teach: Motivating factors and implications for recruitment. Evaluation and Research in Education, 15(1), 17-32.

Murnane, R. J., Singer, J. D., Willett, J. B., Kemple, J. J., \& Olsen, R. J. (1991). Who will teach? Policies that matter. Cambridge, MA: Harvard University Press.

Newby, D., Smith, G., Newby, R., \& Miller, D. (1995). The relationship between high school students' perceptions of teaching as a career and selected background characteristics: implications for attracting students of color to teaching. Urban Review, 27(3), 235-249. http://dx.doi.org/10.1007/BF02354399

O'Connor, M. (1999). Why don't students want to be teachers? Education Review, 3(3), 15.

OECD. (2005). Teachers matter: Attracting, developing and retaining effective teachers. Paris: OECD.

Ozbek, R. (2007). O“ g retmen adaylarının o"g gretmenlik mesleg ini tercih etmelerinde kis, isel, ekonomik ve sosyal fakto"rlerin etkililik derecesine ilis, kin algıları. [Teacher candidates' perceptions about importance of personal, economic and social factors which affect their decisions to be teachers]. Firat U" niversitesi Sosyal Bilimler Dergisi, 17(1), 145-160.

Papanastasiou, C., \& Papanastasiou, E. (1997). Factors that influence students to become teachers. Educational Research and Evaluation, 3(4), 305-316.

Papanastasiou, C., \& Papanastasiou, E. (1998). What influences students to choose the elementary education major: The case of Cyprus. Mediterranean Journal of Educational Studies, 3, 35-45.

Parr, M., Gosse, D., \& Allison, J. (2008). The professional journey of male primary teachers: Experiences and perceptions of entering into a "sacred female space". The International Journal of Diversity in Organizations, Communities and Nations, 7(6), 257-265.

Prabjandee, D. (2014). Journey to Becoming a Thai English teacher: A new perspective on investigating teacher shortage. Alberta Journal of Educational Research, 60(3), 522-537.

Preston, B. (2002). Tracking trends in principal and teacher demand and supply. In the annual Australian Association for Research in Education Conference symposium "Are Australian schools running out of potential principals?", Brisbane, Queensland.

Priyadharshini, E., \& Robinson-Pant, A. (2003). The attractions of teaching: An investigation into why people change careers to teach. Journal of Education for Teaching, 29(2), 96-112.

Ramsay, G. (2000). Quality matters. Revitalising teaching: Critical times, critical choices. Report of the review of teacher education, New South Wales. Sydney: NSW Department of Education and Training.

Reid, I., \& Caudwell, J. (1997). Why did secondary PGCE students choose teaching as a career? Research in Education, 58, 46-58.

Roness, D., \& Smith, K. (2010). Stability in motivation during teacher education. Journal of Education for Teaching, 36(2), 169-185.

Saban, A. (2003). A Turkish profile of prospective elementary school teachers and their views of teaching. Teaching and Teacher Education, 19, 829-846.

Sahin, A., Cokadar, H., \& Usak, M. (2008). Context, process and change: The status of prospective teachers' perception of teaching process. Essays in Education, 23.

Sinclair, C. (2008). Initial and changing student teacher motivation and commitment to teaching. Asia-Pacific Journal of Teacher Education, 36(2), 79-104.

Sinclair, C., Dowson, M., \& McInerney, D. (2006). Motivations to teach: Psychometric perspectives across the first semester of teacher education. Teachers College Record, 108(6), 1132-1154.

Smedley, S. (2007). Learning to be a primary school teacher: Reading one man's story. Gender and Education, 19(3), 369-385.

Smethem, L. (2007). Retention and intention in teaching careers: Will the new generation stay? Teachers and Teaching, 13(5), 465-480.

Spear, M., Gould, K., \& Lee, B. (2000). Who would be a teacher? A review of factors motivating and demotivating prospective and practising teachers (Slough, National Foundation for Educational Research).

Stiegelbauer, S. (1992). Why we want to be teachers: new teachers talk about their reasons for entering the profession, Paper presented at the annual meeting of the American Research Association, San Francisco, CA. Retrieved from ERIC database (ED348367)

Tabberer, R. (2003). Promoting teacher quality in England: The role of the teacher training agency. In the Proceedings of the ACER Research Conference "Building teacher quality. What does the research tell us?" (pp. 2-6). Melbourne.

Thornton, M., P. Bricheno, and I. Reid. 2002. Students` reasons for wanting to teach in primary school. Research 
in Education 67: 33-43

Topkaya, E. Z., \& Uztosun, M. S. (2012). Choosing teaching as a career: motivations of preservice English teachers in Turkey. Journal of Language Teaching and Research, 3(1), 126-134.

Ubuz, B., \& Sarı, S. (2008). Sınıf öğretmeni adaylarının öğretmenlik mesleğini seçme nedenleri. Pamukkale Üniversitesi Eğitim Fakültesi Dergisi, 24, 113-119.

Watt, H. M. G., \& Richardson, P. W. (2007). Motivational factors influencing teaching as a career choice: development and validation of the FIT-Choice scale. The Journal of Experimental Education, 75(3), 167-202.

Watt, H. M. G., Richardson, W. P., Klusmann, U., Kunter, M., Beyer, B., Trautwein, U., et al. (2012). Motivations for choosing teaching as a career: An international comparison using the FIT-Choice scale. Teaching and Teacher Education, 28, 791-805.

Watt, H. M. G., \& Richardson, P. W. (2008). Motivations, perceptions, and aspirations concerning teaching as a career for different types of beginning teachers. Learning and Instruction, 18, 408-428.

Yong, B. C. (1995). Teacher trainees' motives for entering into a teacher career in Brunei Darussalam. Teaching and Teacher Education, 11(3), 275-280.

Young, B. J. (1995). Career plans and work perceptions of pre-service teachers. Teaching and Teacher Education, 11(3), 281-292. 